\title{
Modelowanie matematyczne w językoznawstwie. Na przykładzie statystycznych praw językowych
}

\section{Agnieszka Kułacka}

King's College London

\section{Wstęp}

Modelowanie matematyczne jest techniką stosowaną w wielu dziedzinach nauki, przede wszystkim w naukach ścisłych, gdzie języka matematyki używa się do opisania problemu i rozwiązania go na poziomie abstrakcyjnym. Uzyskane wyniki interpretuje się później w dziedzinie wyjściowej. Istotnym elementem budowania modelu jest uwzględnienie w nim tylko istotnych elementów i pominięcie tych, które nie odgrywają w opisywanym procesie zasadniczej roli. W innych przypadkach celowo pomija się część zmiennych, by sprawdzić, jaki mają wpływ na przebieg obserwowanego zjawiska.

W niniejszym rozdziale przyjrzymy się zastosowaniu modelowania matematycznego w językoznawstwie na przykładzie statystycznych praw językowych. Należy zaznaczyć, że nie jest to jedyny obszar w lingwistyce, gdzie wykorzystywane jest modelowanie matematyczne. Stosuje się je również przy badaniu znaczenia w semantyce i pragmatyce formalnej czy też $\mathrm{w}$ analizie mowy $\mathrm{w}$ fonetyce $\mathrm{i}$ fonologii oraz innych dziedzinach językoznawczych.

Nasze rozważania rozpoczniemy od omówienia metody konstruowania prawa nauki, w którym stosuje się modelowanie matematyczne. Wprowadzimy Czytelnika w obszar badań synergetyki oraz pokażemy, że język jest systemem otwartym, co upoważnia nas do jego modelowania w paradygmacie językoznawstwa synergetycznego. W części szóstej przyjrzymy się prawu Menzeratha-Altmanna jako studium przypadku zastosowania modelowania matematycznego.

\section{Metoda konstruowania prawa nauki}

Podstawową metodą badawczą uprawianą przez przedstawicieli szkoły językoznawstwa kwantytatywnego jest metoda hipotetyczno-dedukcyjna. Omówię ją na podsta- 
wie prac Nauka w oczach filozofa J. Kemeny'ego (Kemeny, 1967) oraz Pojęcie nauki $i$ klasyfikacja nauk S. Kamińskiego (Kamiński, 1970). Metoda ta ma formę algorytmu składającego sie z kilku etapów. Szczegółowy opis każdego z etapów poprzedzę grafem (rys. 1) ilustrującym przebieg powstawania prawa naukowego za pomocą metody naukowej.

Konstrukcję prawa rozpoczyna się od sformułowania problemu, któremu podporządkowane jest gromadzenie faktów weryfikujących postawioną hipotezę. Efektem tego badania jest dostrzeżenie prawidłowości (1), które, jeśli ona istnieje, zamyka etap pierwszy. Problem stawia sie jako pytanie, które jest sformułowane:

serio (ani retorycznie, ani dydaktycznie), poprawnie (jest sensowne, jednoznaczne i precyzyjne), trafnie (ani nie implikuje fałszywych założeń, ani nie prowadzi do fałszu), zasadnie (gdy na gruncie dotychczasowej wiedzy wziętej obiektywnie zachodzi wątpliwość, a przy tym pytanie to ma co najmniej dwie możliwe odpowiedzi) i rozstrzygalne (istnieje efektywny sposób okazania, że w zbiorze możliwych odpowiedzi właściwych na dane pytanie jest co najmniej jedna prawdziwa). (Kamiński, 1970: 166)

Dostrzeżenie prawidłowości jest pierwszą fazą rozwiązywania postawionego problemu, prowadzącą do sformułowania prawa nauki.

Następnie drogą indukcji powstaje pierwsza wersja prawa — prawo idealizacyjne (2). Indukcja jest rozumowaniem polegającym na wyprowadzaniu wniosków ogólnych z obserwacji jednostkowych. W prawie idealizacyjnym fakty pełnią rolę drugorzędną, służą tylko do potwierdzenia konieczności zajmowania się zaobserwowaną zależnością między zjawiskami. Zależność ta jest ujęta w formie hipotezy, której prawdziwość musi zostać zweryfikowana. W wyżej wspomnianej hipotezie wykorzystuje się zmienne $\left\{x_{1}, x_{2}, \ldots, x_{\mathrm{n}}\right\}$ definiowalne w danej dziedzinie $D$, które wchodzą z sobą w pewną relację $F$, opisaną wzorem:

$$
\left(\forall x_{1}, x_{2}, \ldots, x_{\mathrm{n}} \in D\right)\left(C_{1}, C_{2}, \ldots, C_{\mathrm{w}} \rightarrow F\left(x_{1}, x_{2}, \ldots, x_{\mathrm{n}}\right)=\text { constans }\right),
$$

gdzie $C_{1}, C_{2}, \ldots, C_{\mathrm{w}}$ to pewne warunki początkowe lub graniczne. Należy zauważyć, że dokonuje się uproszczeń, pomijając nieistotne na tym etapie warunki i okoliczności zachodzenia prawa, pozostawiając jedynie grupę $C_{1}, C_{2}, \ldots, C_{\mathrm{w}}$.

W etapie trzecim (3) dokonuje się wstępnej oceny prawa oraz jego interpretacji w wyjściowej dziedzinie. Następnie dedukcyjnie wyprowadza się z prawa konsekwencje empiryczne (4). Wnioskowanie dedukcyjne jest wnioskowaniem niezawodnym, w którym z prawdziwych przesłanek (tutaj są to założenia o charakterze hipotetycznym) zawsze wynika prawdziwy wniosek.

Kolejnym etapem badań jest poddanie hipotezy testom. Projektuje się eksperymenty, których wynik wskaże na przyjęcie lub odrzucenie prawa idealizacyjnego (5a). Dokonuje się też faktualizacji prawa (5b), polegającej na uwzględnieniu zaobserwowanych faktów i aktualizacji relacji $F$, jeśli empiria nie potwierdza dedukcyjnego rozumowania.

Etap piąty zamknięty jest pętlą algorytmu, czyli powtarza się kolejno jego podetapy, (5a)-(5b)-(5c), aż do uzyskania zadowalających wyników. Po dokonaniu dostatecznej liczby testów prawo faktualne (5c) przyjmuje się i dołącza do istniejącego 
„gmachu” wiedzy, zachowując zasadę koherencji, tj. niesprzeczności z dotychczasową wiedzą (6).

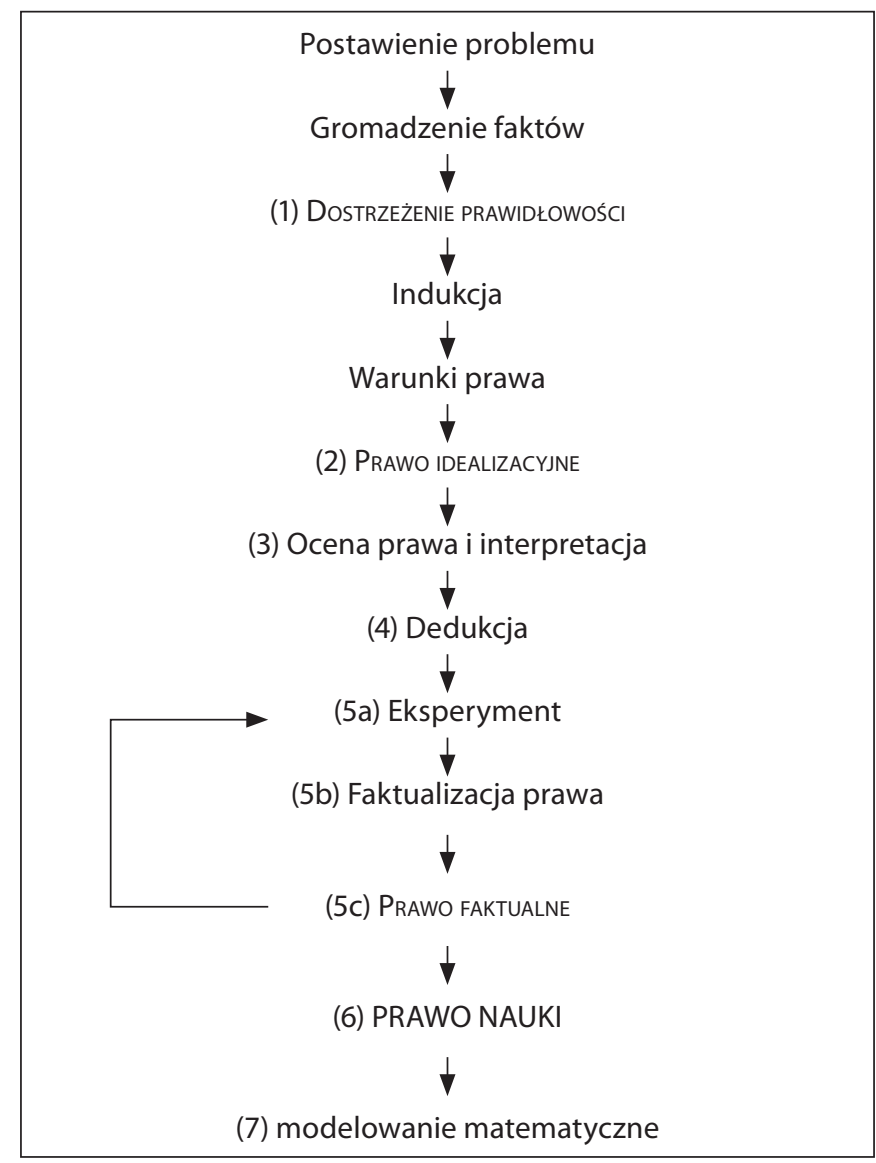

Rysunek 1. Konstrukcja prawa nauki

Fakultatywnym etapem siódmym może być modelowanie matematyczne (7) w sensie węższym¹, które składa się z kolejnych podetapów (rys. 2).

Prawo nauki zostaje przełożone na język matematyki, czyli relację $F$ zapisuje się za pomocą odpowiednich wzorów (7a). Przeprowadza się badania empiryczne (7b) i wyniki porównuje (7d) z danymi teoretycznymi uzyskanymi z obliczeń dokonanych dzięki zastosowanym wzorom matematycznym (7c). Jeśli wyniki empiryczne znacznie różnią się od danych teoretycznych, wzór poprawia się (7e) i powtarza się podetapy $(7 \mathrm{~b})-(7 \mathrm{c})-(7 \mathrm{~d})-(7 \mathrm{e})$, aż do uzyskania zadowalających rezultatów. Ostatnim podetapem jest sporządzenie raportu z badań i zaproponowanie wzoru opisującego prawo nauki $(7 \mathrm{f})$.

1 Cały proces konstrukcji prawa nauki można również nazwać modelowaniem matematycznym (w sensie szerszym). 


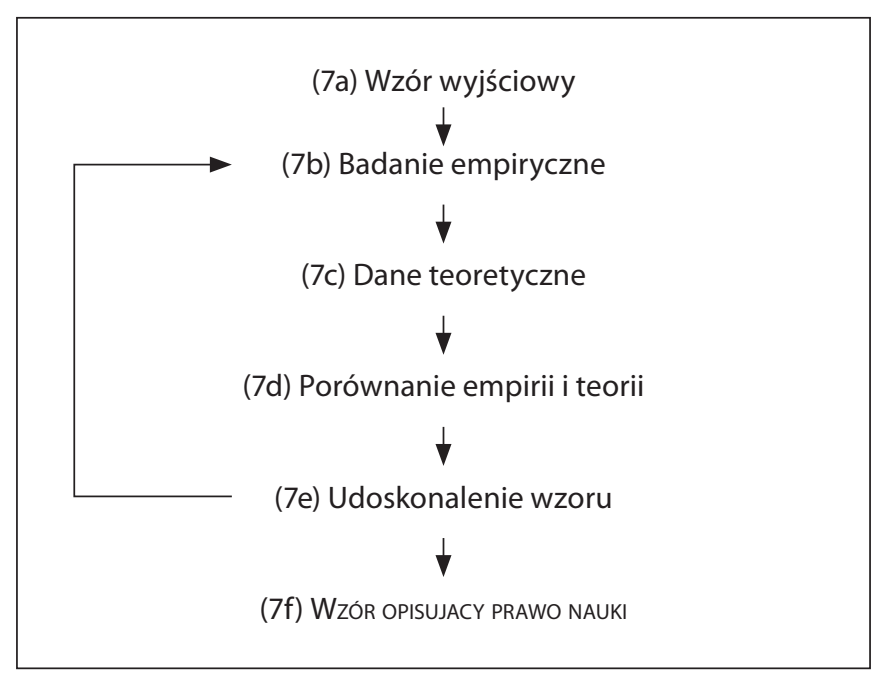

Rysunek 2. Modelowanie matematyczne

Opisana w tym rozdziale metoda jest pozytywną weryfikacją prawa, zwaną też jego konfirmacją. Inną procedurą stosowaną w nauce jest falsyfikacja teorii nauk, czyli wykazanie fałszywości hipotez. Celem tej procedury jest odrzucenie danej teorii nauk. Falsyfikowanie hipotez pretendujących do pozycji prawa nie jest odpowiednią metodą badania, ponieważ na etapie (1) nastąpiło już dostrzeżenie prawidłowości, którą się później konfirmuje, poprawia lub odrzuca, jeśli dalsze badania jej nie potwierdzają.

\section{Synergetyka}

W roku 1983 Hermann Haken zapoczątkował badania w nowej dziedzinie nauki, którą nazwał synergetyką od greckich słów sin „wspólny” i ergos „działanie”. Naukowcy uprawiający synergetykę, zajmują się odpowiedzią na pytanie, czy istnieją ogólne prawa lub zasady rządzące procesami w systemach samoorganizujących się — takich, jakimi są systemy otwarte. Celem synergetyki jest znalezienie i opis tych praw, zakładając, że istnieją one niezależnie od rodzaju systemu: od społeczności ludzkich po podgrzane ciecze.

Badania synergetyczne, według Hakena (1998), należy rozpocząć od odpowiedniego opisu stanu systemu. Opis ten zależy od poziomu, jaki chcemy badać: czy interesuje badacza poziom indywidualnych elementów systemu i ich interakcji, czy też grup elementów i procesów zachodzących między nimi. Jako przykład Haken podaje ruch przechodniów. Można śledzić wędrówkę każdego z nich z osobna na pewnym odcinku chodnika. Można badać średnią liczbę przechodniów i ich prędkość chodzenia na pewnej przestrzeni chodnika. Można też obserwować wzory zachowań przechodniów, np. czy ruch jest jednostronny, dwustronny, czy też chaotyczny (por. Haken, 1998: 59-60).

Synergetyka zajmuje się również badaniem sytuacji, kiedy zachowanie się systemu zmienia się jakościowo przy zmianie parametrów kontrolnych. Parametry kontrolne są to wielkości zewnętrzne wpływające na działanie systemu, ale na pewien określony 
czas dla tego systemu stałe. W przykładzie z przechodniami parametrem kontrolnym może być szerokość wejścia do stacji metra lub liczba przechodniów wchodzących i wychodzących. Na skutek zmiany parametru kontrolnego system zmienia strukturę dzięki możliwości samoorganizacji (por. Haken, 1998: 60).

W wielu wypadkach zachowanie systemu może być reprezentowane przez kilka wielkości kolektywnych, nazywanych parametrami porządku. Wystarczy obserwować ich zachowanie zamiast zachowania wszystkich elementów systemu; zjawisko to nosi nazwę kompresji informacji. Parametry porządku nie tylko reprezentują, ale również determinują zachowanie się elementów systemu (por. Haken, 1998: 60). Przykładem parametrów porządku mogą być pracownicy metra. W czasie godzin szczytu na stacjach metra w Londynie pojawiają się na peronach dodatkowi pracownicy, którzy przez megafon instruują pasażerów, by zanim wsiądą, pozwolili wysiąść, by zajmowali całą możliwą przestrzeń w pociągach itd. Obecność tych pracowników jest z kolei generowana przez liczbę pasażerów. Mówimy tu więc o przyczynowości cyrkularnej, która w ogólnej teorii systemów nazywa się informacją zwrotną (por. Haken, 1998: 60-61). Warto zauważyć, że parametry porządku wykazują znacznie mniejszą podatność na zmiany niż każdy pojedynczy podsystem (Fleischer, 2002: 139).

\section{Język jako system otwarty}

Czy język jest systemem? Język jest uporządkowanym wewnętrznie układem znaków posiadających określoną strukturę i wchodzących z sobą w reakcje. Ponadto język wchodzi w reakcje ze swoim środowiskiem, którym może być myśl ludzka. Nowe znaki są dodawane przez użytkowników, a inne wychodzą z użycia. Język jest więc nie tylko systemem, ale jest systemem otwartym, wymieniającym energię ze swoim środowiskiem.

Wymiana energii, materii lub informacji systemu językowego ze swoim środowiskiem, czyli użytkownikami języka, podobnie jak inne systemy otwarte, charakteryzuje sie negatywną entropią, informacją zwrotną, homeostazą, różnicowaniem, ekwifinalnością. Przyjrzymy się każdej z tych cech z osobna.

Negatywna entropia powoduje, że zachowany jest porządek w systemie. Ostatnie badania nad językiem (por. Köhler, 1993, Köhler, 2005) wykazały, że język jest również systemem samoregulującym i posiadającym parametry porządku. Są nimi: (1) minimalizacja wysiłku produkcji informacji, (2) minimalizacja wysiłku pamięci, (3) minimalizacja wysiłku dekodowania informacji. Efektem działania dwóch pierwszych parametrów byłoby maksymalne podobieństwo pomiędzy znakami języka. Wpływają więc one na ograniczenie inwentarza znaków. Istnienie trzeciego parametru powoduje poszerzenie zasobu znaków.

System językowy nieustannie monitoruje komunikację, by zabezpieczyć osiągniecie jej celu przez użytkowników. Wysyłany komunikat językowy trafia do receptorów (narządy słuchu bądź/i wzroku), które przesyłają informację do mózgu. Mózg interpretuje informację i wysyła odpowiedź do efektorów (narządy mowy bądź/i ruchu). Stanowi to część informacji zwrotnej na temat tego, czy cel komunikacji został osiągnięty. W tym kontekście doskonale widać, na czym polega wymiana materii systemu językowego ze środowiskiem, czyli jego użytkownikami. Język dostarcza materiału do wyrażenia myśli, natomiast użytkownicy potrafią wpływać na ten ma- 
teriał, powodując jego zmiany, które - jeśli są zaakceptowane poprzez użycie przez większość - stają się zmianami trwałymi.

Inną cechą charakterystyczną wymiany materii języka z użytkownikami jest homeostaza, czyli zdolność do utrzymania stanu równowagi dynamicznej języka, w którym zachodzą procesy zmian. Jakiejkolwiek natury są zmiany językowe, czy dotyczą gramatyki, czy słownictwa, system zachowuje równowagę i jest w stanie sprostać tym samym zadaniom komunikacyjnym.

Różnicowanie elementów języka czy jego podsystemów oznacza, że wyspecjalizowane jednostki pełnią określone funkcje w procesach zachodzących w systemie. Poziom fonetyczny języka odpowiada między innymi za zmiany fonetyczne. Na poziomie morfologicznym mamy do czynienia z odmianą części mowy, derywacją nowych słów z już istniejących w języku. Procesy, jakie zachodzą na poziomie leksykalnym, to tworzenie nowych słów i zapożyczenia słownikowe z innych języków. Za zapożyczenia struktur gramatycznych odpowiada poziom składniowy. Na poziomie semantycznym odbywa się tworzenie pojęć i nowatorskie wykorzystanie istniejących słów. Poziom pragmatyczny to przede wszystkim dodatkowe asocjacje użytkowników, powstałe dzięki wykorzystywanym jednostkom języka. Są to oczywiście tylko wybrane procesy zachodzące na każdym z tych poziomów.

Ostatnią z wymienionych wyżej cech charakterystycznych systemu językowego jest jego ekwifinalność, czyli zasada mówiąca, że do tego samego stanu końcowego system może dojść z różnych stanów początkowych. Istnienie ekwifinalności wyjaśnia, dlaczego nie znaleziono dotychczas odpowiedzi na pytanie, jak powstał język. Wszystkie teorie dotyczące początków języka mają taką samą moc eksplanacyjną jego stanu obecnego.

\section{Statystyczne prawa językowe}

Dzięki izomorfizmowi nauk oraz założeniu, że język jest systemem otwartym, badania w paradygmacie synergetycznym można przenieść na grunt badań nad językiem. Korzystając z tego faktu, Reinhard Köhler (1993, 2005) zaprezentował metodę modelowania języka w tym paradygmacie. Składa się ona z sześciu etapów. W pierwszym formułuje się aksjomaty: język jest systemem samoorganizującym się i samoregulującym. Inne aksjomaty to parametry porządku, na przykład: minimalizacja wysiłku produkcji informacji, minimalizacja wysiłku pamięci, minimalizacja wysiłku dekodowania informacji. Drugi etap to decyzja, które z poziomów czy elementów systemu należy opisać na potrzeby bieżących badań. W kolejnym etapie badacz stawia hipotezy dotyczące: wpływu jednych elementów lub poziomów systemu na inne, tego, jakie są tego konsekwencje, efekty i interrelacje między nimi. Etap czwarty i piąty to poszukiwanie i dobór odpowiednich funkcji matematycznych, by oddać te relacje między elementami lub poziomami systemu. W ostatnim etapie funkcje te poddawane są rygorystycznym testom empirycznym.

Jak można zauważyć, porównując etapy trzeci do szósty metody opisanej przez Köhlera z metodą konstruowania prawa nauki, są one analogiczne. Opisana przeze mnie w części drugiej metoda konstruowania prawa nauki jest może bardziej szczegółowa i kompletna. Nie jest to zaskakujące, ponieważ założony izomorfizm między naukami odpowiada też za stosowanie tych samych technik. Ważny jest tutaj fakt, że 
uzasadnia to poszukiwanie praw językowych oraz metodę ich konstruowania. Aksjomat mówiący, że język jest przede wszystkim systemem, daje możliwość korzystania z matematycznej definicji systemów. Równanie różniczkowe dotyczące wpływu jednych elementów systemu na inne wykorzystują między innymi wzory opisujące prawo Menzeratha-Altmanna.

\section{Prawo Menzeratha-Altmanna. Studium przypadku}

Prawo Menzeratha-Altmanna (dalej: prawo MA) zostało po raz pierwszy dostrzeżone przez francuskiego językoznawcę A. Grégoire’a pod koniec XIX wieku. Jednakże inni językoznawcy nie znali tej prawidłowości dopóki nie została ona opisana i sformułowana dla fonologii przez Paula Menzeratha w 1928 roku. Menzerath zauważył dwie zależności: (a) „im krótsza jest głoska, tym dłuższa jest związana z nią całość [czyli jednostka, w jakiej występuje]” (Menzerath, 1928: 104) oraz (b) „że trzysylabowe słowo z ośmioma głoskami trwa relatywnie dłużej niż trzysylabowe słowo z dziewięcioma lub więcej głoskami [czyli im więcej głosek w wyrazie, tym są one krótsze]" (Menzerath, 1928: 104). Następnie odkrył on, że im dłuższe jest słowo, tym krótsze są jego sylaby (Altmann, 1980). Wreszcie w roku 1954 uogólnił to statystyczne prawo fonologiczne na cały system językowy. Wzajemną relację między składnikiem a całością, wyrażoną prawem Menzeratha-Altmanna, można ująć w następujący sposób (Menzerath, 1954, cyt. za Hammerl, Sambor, 1993: 23):

(2) im dłuższa konstrukcja językowa, tym krótsze są jej składniki.

Prawem MA zajmowano się na wielu poziomach języka: na poziomie fonologicznym, gdzie prawo to odkryto, poprzez poziom morfologiczny, składnię, semantykę oraz na poziomie dyskursu. W poniższych częściach prześledzimy modelowanie matematyczne w sensie szerszym, zastosowane przy konstrukcji prawa nauki. Prawo MA badałam na poziomie składni, czyli potwierdziłam, że statystycznie im dłuższe jest zdanie złożone, tym krótsze są jego zdania podrzędne.

\subsection{Metoda badań nad prawem MA}

Po dostrzeżeniu prawidłowości, które zakończyło etap pierwszy badań nad prawem MA, opracowano metodę badań, udoskonaloną przeze mnie i szczegółowo opisaną w Kułacka (2008) i Kułacka (2009c). Polega ona na wykorzystaniu współczynnika korelacji rangowej Spearmana w celu potwierdzenia zaobserwowanej prawidłowości. Współczynnik ten stosuje się w badaniach nad korelacją hierarchii ujętej rangami. Mamy tu do czynienia z hierarchią długości zdań złożonych i hierarchią zdań podrzędnych.

Same badanie nad prawem MA przeprowadzane było dwuetapowo. Pierwszy etap stanowiły badania wstępne, po wykonaniu których postawiłam hipotezy dotyczące warunków zachodzenia prawa oraz współczynników występujących we wzorze opisującym prawo. Badania właściwe (drugi etap) potwierdziły pięć z postawionych hipotez i odrzuciły szóstą. Ten etap indukcyjny poprzedził następny, w którym dostrzegłam początkowe oraz graniczne warunki prawa $C_{1}, C_{2}, \ldots, C_{w}$, by prawo za- 
chodziło. Należy wspomnieć, że po ograniczeniu zakresu zachodzenia prawa przez wspomniane wyżej warunki, prawo zachodziło na badanych tekstach.

\subsection{Warunki prawa}

Warunkiem początkowym zachodzenia prawa jest badanie zamkniętych odcinków tekstów. Mam tu na myśli rozdziały książek w przypadku badań nad tekstami pisanymi. Wykazałam, że jeśli analizuje się przypadkowy zbiór zdań, prawo MA nie zachodzi. Innym warunkiem początkowym, który ogranicza zakres zachodzenia praw statystycznych jest wielkość próby. Prawo nie zachodzi dla stosunkowo krótkiego odcinka tekstu. Odkryłam dla prawa MA, że długość minimalnego odcinka tekstu, na którym prawo działa w składni, zależy także od struktury składniowej tekstu, a nie tylko od liczby przebadanych zdań. Jeśli mamy tekst charakteryzujący się dużą liczbą zdań pojedynczych rozwiniętych oraz zdań wielokrotnie złożonych, to prawo zachodzi na krótszym odcinku tekstu niż w przypadku tekstu o uboższej strukturze składniowej. Moje badania przeprowadzałam porównawczo na tekstach literackich i naukowych. Pozwoliło mi to na dostrzeżenie kolejnego warunku początkowego: długość minimalnego odcinka tekstu, dla którego prawo zachodzi dla tekstów naukowych jest mniejsza niż dla tekstów literackich.

W czasie moich badań właściwych odkryłam również jeden warunek graniczny zachodzenia prawa MA. Może ono nie zachodzić dla tekstów, których długość zdań jest mniejsza od pewnej wartości. Wartość ta jest różna dla języka angielskiego i polskiego.

Warunki prawa MA, szczegółowo opisane w Kułacka (2009a), pozwoliły na zaproponowanie prawa idealizacyjnego, w formie powyższego wzoru (1). Kolejnym etapem modelowania matematycznego jest interpretacja prawa w dziedzinie wyjściowej, czyli językoznawstwie. Zostanie ona przeprowadzona przy wsparciu o psycholingwistykę.

\subsection{Interpretacja prawa}

Interpretację prawa MA omówię pokrótce na poziomie składni. Załóżmy, że mamy od czynienia ze zdaniem złożonym. Elementy informacji, jakie składają się na całość sensu wyrażonego przez zdanie, to liczba wyrazów, złożoność sposobu ich wypowiadania, złożoność morfologiczna i semantyczna wyrazów, złożoność połączeń syntaktycznych między nimi oraz złożoność połączeń syntaktycznych między zdaniami składowymi. Dla każdego z wymienionych tu elementów informacji zarezerwowany jest pewien poziom aktywacji. Liczba wszystkich aktywacji przebiegających jednocześnie nie może przekroczyć maksymalnego zakresu, czyli pojemności pamięci operacyjnej. Jeśli więc dla aktywacji złożoności połączeń syntaktycznych między zdaniami składowymi zarezerwowana jest większa cześć pamięci operacyjnej, mniejsza jej cześć może być przeznaczona na pozostałe elementy informacji, w tym na złożoność połączeń syntaktycznych między wyrazami oraz liczbę wyrazów wykorzystanych w zdaniach składowych. Z tym ostatnim elementem związane są: złożoność sposobu wypowiadania wyrazów oraz ich złożoność morfologiczna i semantyczna. Wyjaśnia to konieczność zachodzenia prawa Menzeratha-Altmanna dla składni: im bardziej złożone zdanie, tym mniej złożone są zdania składowe (Kułacka, 2009b). 
Wiemy teraz, dlaczego prawo nie zachodziło, gdy pomijało się warunek graniczny. Jeśli długość zdań złożonych nie przekracza pewnej wartości, czyli są one na tyle krótkie, że nie obciążają pamięci krótkoterminowej, to prawo może nie zachodzić. Warunek ten jest konieczny. Cały zespół dotychczas odkrytych warunków okazuje się wystarczający, by dedukcyjnie wyprowadzić konsekwencje empiryczne, czyli hierarchię zdań składowych odpowiadającą hierarchii zdań złożonych, ujętą w formie prawa MA. Potwierdziły je dalsze eksperymenty wchodzące w skład badań właściwych. Prawidłowość okrytą pod koniec XIX wieku można włączyć w system praw nauki.

\subsection{Wzory opisujące prawo}

Jak wspomniałam w części drugiej, fakultatywnym etapem siódmym jest modelowanie matematyczne w sensie węższym, czyli znalezienie modelu matematycznego opisującego prawo. Gabriel Altmann (1980) wyprowadził z postawionych założeń dotyczących relacji między zmianą długości składnika a jego długością, a także między wartością tej relacji a długością konstrukcji językowej, równanie różniczkowe. Równanie to rozwiązał metodami rachunku różniczkowo-całkowego i uzyskał model opisujący prawo. Jest to model właściwy dla jednostek ciągłych. Dla danych dyskretnych uzyskano alternatywny model, rozwiązując początkowe równanie za pomocą równań rekurencyjnych (Kułacka, Mačutek, 2007).

W mojej analizie badań właściwych porównałam dane empiryczne i teoretyczne. Były one w zadowalający sposób do siebie zbliżone. We wzorze dla danych dyskretnych, właściwym dla badań przy jednostkach będących liczbą wyrazów i liczbą zdań składowych, pojawiają się współczynniki $y(1)$, czyli długość zdania pojedynczego, oraz $b$, który odpowiada za zmiany struktury składniowej tekstu wraz z wydłużaniem badanego odcinka tekstu. Im jest on mniejszy (należy zauważyć, że przyjmuje on wartości ujemne), tym zmiany te są większe. W czasie badań właściwych potwierdziłam dwie hipotezy dotyczące wartości tych współczynników. Wartość współczynnika $y(1)$ dla tekstu literackiego jest mniejsza od 10, a dla tekstów naukowych większa od 10. Wartość współczynnika $b$ dla tekstów literackich jest większa od $-0,11$, a dla tekstów naukowych mniejsza od $-0,11$. Wartość współczynnika $y(1)$ jest większa w języku angielskim (językach izolujących?) niż w języku polskim (językach fleksyjnych?), natomiast wartość współczynnika $b$ jest, w granicach błędu statystycznego, stała dla danego tekstu i niezależna od języka².

\section{Wnioski końcowe}

Na przykładzie prawa MA prześledziliśmy proces konstrukcji prawa nauki w językoznawstwie, które nazwać można modelowaniem matematycznym w sensie szerszym. W literaturze naukowej dotyczącej prawa MA istnieją przykłady jego zastosowania w innych dziedzinach nauki: w genetyce, prymatologii, muzykologii i innych. Można więc pokusić się o stwierdzenie, że prawo MA jest jednym z ogólnych praw rządzą-

2 Zob. szczegóły w Kułacka, 2009a. 
cych procesami w systemach samoorganizujących się (por. część trzecia). Procesy opisane w części szóstej dotyczą tworzenia zdań złożonych w systemie otwartym, jakim jest język. Prawo MA jest zapewne jednym z najlepiej zbadanych statystycznych praw językowych. Istnieje bogata literatura na jego temat. Miejmy nadzieję, że inne statystyczne prawa językowe doczekają się podobnego zainteresowania i okaże się, że one również wykraczają swoim zasięgiem poza dziedzinę językoznawstwa.

\section{Bibliografia}

Altmann, G., 1980, Prolegomena to Menzerath's Law, [in:] R. Grotjahn (ed.), Glottometrika 2. Bochum: Studienverlag Dr. N. Brockmeyer, 1-10.

Fleischer, M., 2002, Teoria kultury i komunikacji. Systemowe i ewolucyjne podstawy, Wrocław: Dolnośląska Szkoła Wyższej Edukacji Towarzystwa Wiedzy Powszechnej.

Haken, H., 1998, Can we apply synergetics to the human sciences?, [in:] G. Altmann, W. K. Koch (ed.), Systems. New Paradigms for the Human Sciences, Berlin: de Gruyter, 58-78.

Hammerl, R., J. Sambor, 1993, O statystycznych prawach językowych, Warszawa: Zakład Semiotyki Logicznej Uniwersytetu Wrocławskiego.

Kamiński, S., 1970, Pojęcie nauki i klasyfikacja nauk, Lublin: Towarzystwo Naukowe Katolickiego Uniwersytetu Lubelskiego.

Kemeny, J., 1967, Nauka w oczach filozofa, Warszawa: Wydawnictwo Naukowe PWN.

Kułacka, A., 2008, Badania nad prawem Menzeratha-Altmanna, [w:] M. Skarżyński (red.), „LingVaria” 2(6), 167-174.

Kułacka, A., 2009a, On the Nature of Statistical Language Laws, [in:] P. Stalmaszczyk (ed.), Philosophy of Language and Linguistics. Volume I: The Formal Turn, w druku.

Kułacka, A., 2009b, The Necessity of the Menzerath-Altmann Law, [in:] A. Michońska-Stadnik (ed.), Anglica Wratislabiensia XLVII, w druku.

Kułacka, A., 2009c, Warunki zachodzenia prawa Menzeratha-Altmanna, [w:] M. Skarżyński (red.), „LingVaria” 1(7), 17-28.

Kułacka, A., J. Mačutek, 2007, A Discrete Formula for the Menzerath-Altmann Law, "Journal of Quantitative Linguistics“ Vol. 14, 23-32.

Köhler, R., 1993, Synergetic Linguistics, [in:] R. Köhler, B. B. Rieger (ed.), Contributions to Quantitative Linguistics, Londyn: Kluwer Academic Publishers, 41-51.

Köhler, R., 2005, Synergetic Linguistics, [in:] R. Köhler, G. Altmann, R. G. Piotrowski (ed.), Quantitative Linguistics. An International Handbook, Berlin: Mouton de Gruyter. 760-774.

Menzerath, P., 1928, Über einige phonetische Probleme, Actes du premier Congres international de linguists, Leiden. 104-105. 